NBER WORKING PAPER SERIES

\title{
QUALITY ADJUSTED COST FUNCTIONS FOR CHILD CARE CENTERS
}

\author{
H. Naci Mocan
}

Working Paper No. 5040

\section{NATIONAL BUREAU OF ECONOMIC RESEARCH 1050 Massachusetts Avenue \\ Cambridge, MA 02138}

February 1995

This research is supported by grants from the Carnegie Foundation of New York, Packard Foundation, and Pew Foundation. Joseph Ron White, Daniel Rees and Sarah Price provided outstanding research assistance at every stage of the project. I thank Tim Martin, Elena Pestchanskaia and Alptekin Avcioglu for their assistance in final stages of data clean-up. I also thank David Blau, Heidi Hartmann, Suzanne Helburn, Ellen Magenheim, John R. Morris, Barbara Robles, W. James Smith, and especially Jeffrey S. Zax for helpful discussions. This paper is part of NBER's research programs in Health Economics and Labor Studies. Any opinions expressed are those of the author and not those of the granting agencies, the University of Colorado at Denver, or the National Bureau of Economic Research.

(C) 1995 by H. Naci Mocan. All rights reserved. Short sections of text, not to exceed two paragraphs, may be quoted without explicit permission provided that full credit, including (C) notice, is given to the source. 


\title{
QUALITY ADJUSTED COST FUNCTIONS FOR CHILD CARE CENTERS
}

\begin{abstract}
Using a newly compiled data set, this paper estimates multi-product translog cost functions for 399 child care centers from California, Colorado, Connecticut, and North Carolina. Quality of child care is controlled by a quality index, which has been shown to be positively related to child outcomes by previous research. Nonprofit centers that receive public money, either from the state or federal government, (which is tied to higher standards), have total variable costs that are 18 percent higher than other centers, keeping quality of services constant.

No statistically significant differences between general categories of for-profit and nonprofit centers are detected. Furthermore, various types of nonprofits are not distinguishable from their for-profit counterparts. In agreement with previous studies, the data show that the average quality of center-based child care is between "minimal" and "good", and it costs 13 cents per hour per child to increase this average quality to the level considered developmentally appropriate by child care experts.
\end{abstract}

H. Naci Mocan

Department of Economics

University of Colorado at Denver

Campus Box 181, PO Box 173364

Denver, CO 80217-3364

and NBER 


\section{Introduction}

In 1990, there were 27.6 million U.S. households with children under age 13 , and in these households there were 47.7 million children. The primary child care arrangement for 6.2 million of these children was center-based day care. Although most nonworking mothers care for their children themselves, nearly one out of every three nonworking mothers relies on center-based programs for three-to-four-year-old children (Sandra Hoffert et al., 1991). The U.S. Department of Commerce reported that families with employed women spent an estimated $\$ 21$ billion on child care in 1988 , and women in poverty pay approximately 21 percent of their family income for child care (U.S. Department of Commerce, 1992).

The average quality of center-based care provided in the United States is below the level that is considered good by professionals in early care and education (e.g. Marcy Whitebook et al., 1990), On the other hand, there is growing evidence linking the quality of childhood care and education to child development. High quality child care programs have been shown to reduce the likelihood of enrolling in special education programs (Irving Lazar, et al., 1982) and to improve the academic outcomes of children (Craig Ramey and Frances Campbell, 1991). It is therefore critical to develop an understanding of the determinants of cost of child care, and the relationship between cost and quality, especially because of current legislative climate in the U.S. The Welfare Reform Act and the Child Care and Development Block Grant are up for reauthorization, both of which will have far-reaching consequences for the child care market. The legislative decisions on these policies may impact female labor force 
participation behavior, as well as the federal and state grants and subsidies that are directed to child care centers.

Using an extensive data base that has recently been constructed from 399 child care centers in California, Colorado, Connecticut and North Carolina, this paper investigates two important issues: $i$ ) Is there an efficiency difference between for-profit and nonprofit centers? More precisely, do nonprofit centers produce the same output at similar costs as their for-profit counterparts, or do they waste resources? ii) How much would it cost to increase the quality of care from average to good (as defined by education experts)?

The data are based upon a stratified random sample of approximately 100 day care centers from each participating state, with equal representation of for-profit and nonprofit programs, providing full-time year-around care. The centers were visited during the spring of 1993. Comprehensive financial data, as well as detailed data on structural and process quality of the center and classrooms were collected through interviews, questionnaires and observations. This data set has a number of significant advantages over existing data sets used by previous studies. First, the extraordinary detail pertaining to the cost structures of the centers enables us to measure center costs very accurately. Second, this data sets allows for estimation of a multi-product cost function where the services for infant-toddlers, preschoolers and school-aged children are distinguished. Third, instead of treating labor as one input, labor is classified into teacher, teacher-aide and teacher-director categories. Fourth, the quality of the operation 
is controlled by employing a quality index, which has been widely-used in early childhood education literature.

\section{Empirical Implementation}

Although the objectives of the nonprofit child care centers may differ from those of for-profit centers, under cost minimization and competitive input prices, the short-run cost functions for child care centers can be described by the following translog functional form.

$$
\begin{aligned}
& \operatorname{LnC}=\alpha_{0}+\Sigma \alpha_{i}(\operatorname{LnP})+\beta_{1}(\operatorname{LnK})+(1 / 2) \beta_{2}(\operatorname{LnK})^{2}+(1 / 2) \Sigma \Sigma \gamma_{i j}\left(\operatorname{LnP} P_{i} \operatorname{LnP}\right) \\
& +\Sigma \delta_{i}\left(\operatorname{LnP} P_{i} \operatorname{LnK}\right)+\Sigma \lambda_{k}\left(\operatorname{Ln} Y_{k}\right)+(1 / 2) \Sigma \Sigma \xi_{k s}\left(\operatorname{Ln} Y_{k} \operatorname{Ln} Y_{r}\right)+\Sigma \Sigma \mu_{i k}\left(\operatorname{LnP} P_{i} \operatorname{LnY} Y_{k}\right) \\
& +\Sigma \phi_{k}\left(\operatorname{LnY} Y_{k} \operatorname{LnK}\right)+\eta_{1}(\mathrm{Lnq})+\eta_{2}(\mathrm{Lnq})^{2}+\Sigma \omega_{\mathrm{n}} \mathrm{D}_{\mathrm{n}}+\mathbf{u}_{\mathrm{i}}
\end{aligned}
$$

where $C$ is the total variable $\cos , P_{\mathrm{i}}$ and $P_{\mathrm{j}}$ denote the prices of the $i$ th and $j$ th inputs, respectively, $Y_{\mathrm{t}}$ and $Y_{\mathrm{k}}$ stand for the amounts of the $r$ th and $k$ th output, and $K$ is the amount of physical space, which is fixed in the short-run. $L n$ stands for the natural logarithm, $u$ is the error term, and $q$ represents the quality level of the service provided. The inclusion of the quality index $q$ in equation (1) allows for the control of the variation in costs due to quality differentials between otherwise similar centers. Similarly, a vector of dummy variables $\left(D_{n}\right)$, representing center attributes is included to capture efficiency differentials due to center characteristics. They are defined in the next section.

To be consistent with economic theory, the cost function should be linearly homogenous in input prices, and the cross-coefficients must be symmetric. These imply the following restrictions on Equation (1). 


$$
\begin{aligned}
& \Sigma \alpha_{\mathrm{i}}=1, \Sigma \gamma_{\mathrm{ij}}=0 \text { for all } i, \Sigma \delta_{\mathrm{i}}=0, \text { and } \Sigma_{\mathrm{i}} \mu_{\mathrm{ik}}=0 \text { for all } k \\
& \gamma_{\mathrm{ij}}=\gamma_{\mathrm{ji}} \text { for all } i \text { and } j, \text { and } \xi_{\mathrm{kr}}=\xi_{\mathrm{rk}} \text { for all } k \text { and } r
\end{aligned}
$$

Using Shephard's Lemma, optimal demand for the $i$ th input is obtained by differentiating the cost function with respect to the price of the ith input $\left(\mathrm{P}_{\mathrm{i}}\right)$ which yields:

$$
\partial \operatorname{LnC} / \partial \operatorname{LnP}_{i}=\left(\partial \mathrm{C} / \partial \mathrm{P}_{\mathrm{i}}\right)\left(\mathrm{P}_{\mathrm{i}} / \mathrm{C}\right)=\mathrm{P}_{\mathrm{i}} \mathrm{X}_{\mathrm{i}} / \mathrm{C},
$$

where $\mathrm{X}_{\mathrm{i}}$ is the optimal level of input $i$. Thus, $\mathrm{P}_{\mathrm{i}} \mathrm{X}_{\mathrm{i}} / \mathrm{C}$ is the share of the input $i$ in total variable cost. Letting $S_{i}$ denote the cost share of input $i$, and differentiating the cost function depicted in (1) with respect to $P_{i}$ yields the following structure for the cost shares:

$$
S_{i}=\alpha_{i}+\Sigma \gamma_{i j} \operatorname{LnP}{ }_{j}+\Sigma \delta_{i} \operatorname{LnK}+\sum \mu_{i k} \operatorname{LnY} Y_{k}
$$

The cost equation is estimated jointly with the system of share equations depicted in (3). To avoid singularity in the error covariance matrix, one of the share equations is deleted and the model is estimated using Zellner's Iterative procedure subject to the restrictions imposed above.

\section{Measurement of the Variables}

The data set includes information on 399 child care centers. The dependent variable $(C)$ is the total variable cost of the center during the fiscal year 1991-92. It is the sum of wages, nonwage benefits, staff education costs, subcontracting costs, food costs, maintenance, and other operating expenses. Since nonprofit centers generally receive donations from various sources, the value of donations in the form of food, services, supplies and volunteers are added to the total variable costs. ${ }^{1}$ To the extent that the centers can alter the hours of service provided by the center's director(s), the salaries 
of the directors are also part of the total variable costs. Some for-profit centers are owned and operated by individuals who are also the directors of the center. For those owner-directors who did not report a wage or salary, the salaries are imputed and added to the total variable costs. ${ }^{2}$

INFANT-TODD stands for the output of infant-toddlers produced at the center during the fiscal year 1991-1992. It is the total hours of service provided for infanttoddlers. Similarly, PRESCHOOL and SCHOOLAGE represent the annual hours of care provided for preschoolers and kindergarten-school age children, respectively. These are the output variables, depicted by $\mathrm{Y}$ in Equations (1) and (3). WAGEI is the average wage rate of teachers at the center, weighted by teacher hours. Similarly, WAGE2 and WAGE3 stand for the average teacher aide and teacher-director weighted wages, respectively. These variables represent the prices of variable inputs (P). SPACE is the square footage of the inside space used by children, which is the measure of physical capital (K).

The model includes eight controls for center characteristics $\left(D_{r}\right)$ in Equation (1). PROFIT is a dichotomous variable, which takes the value of one if the center is forprofit, and zero if it is nonprofit. CHAIN is also a dichotomous variable, if the center is part of a for-profit national chain. PUBREGUL is one if the center receives public money, either from the state or federal government, tied to higher standards (above and beyond normal licensing regulations), and zero otherwise. This group includes Head Start centers, centers where 20 percent or more of their enrollment constitute special needs children, special publicly funded preschool programs and other special programs 
in Connecticut and California. PUBAUSP symbolizes centers that are owned and operated by public agencies. Examples include public colleges, hospitals and city departments of family services. PUBSUPP is another dichotomous variable which takes the value one if the center is not publicly owned or operated, but receives more that $\mathbf{5 0}$ percent of its revenue from public grants and/or public fees and/or USDA reimbursement. Also included are the state dummies, which aim to capture statespecific unobservables such as variations in regulatory environment.

In each center two classrooms were randomly selected: one from the older children (30 months and older) and one from the younger groups. In each room wellestablished global measures of child care process were employed by trained observers to assess the quality of the operation. They include the Early Childhood Environmental Rating Scale (ECERS) (Thelma Harms and Richard Clifford, 1980), its infant-toddler version (ITERS) (Thelma Harms et al., 1990), ARNETT scale of teachers sensitivity (Jeffrey Arnett, 1989), Stipek Classroom Observation Measure (Deborah Stipek, 1993), and the Teacher Involvement Scale (Carollee Howes and Phyliss Stewart, 1987). To create a single score to represent classroom process quality, an index was created using principal components techniques. The center level quality index (QUALITY) is the average classroom quality, weighted by enrollments at the appropriate age levels.

IV. Results

The explanatory variables are normalized by dividing each variable by its mean before taking the natural logs. Table 1 reports the estimated model using the whole sample. For brevity, the second order parameters are not reported. ${ }^{3}$ The first-order 
parameters $\left(\lambda_{1}, \lambda_{2}, \lambda_{3}, \alpha_{1}, \alpha_{2}, \alpha_{3}\right)$ are positive and highly significant as suggested by theory, indicating that increases in production levels and the wage rates bring about increases in total variable cost.

The coefficient of the profit dummy $\left(\omega_{1}\right)$ is not significantly different from zero; neither is the coefficient of the dummy for national chains. The sum of the PROFIT and CHAIN coefficients is not significantly different from zero either. On the other hand, the coefficient of PUBREGUL $\left(\omega_{3}\right)$ is 0.169 , and significantly different from zero. This indicates that centers that receive public money, either from the state or federal government, which is tied to higher standards, have variable costs that are 18 percent higher than their non-publicly owned or operated, or publicly supported nonprofit counterparts. ${ }^{4}$ The model is also estimated by including the profit dummy only (i.e without CHAIN, PUBSUPP, PUBAUSP and PUBREGUL). The profit dummy was not significantly different from zero. Both versions of the model are re-estimated using volunteer hours as a fixed input, which involves additional cross terms between volunteer hours, wages and outputs. The results were very similar to the ones reported in Table 1. Similarly, treating directors as a fixed input, and subtracting their salaries from the total variable cost did not alter the results. The hypothesis of no structural difference between nonprofit and for-profit centers could not be rejected either, after estimating the cost functions separately for both categories and applying a standard Chow-test (the Fvalue was 0.38 , with marginal significance level of 0.99 ). The model reported in Table $l$ is re-estimated by including interaction terms between PROFIT and state dummies. The results remained intact. 
The findings indicate that for-profit centers are not distinguishable from nonprofit centers. However, those nonprofit centers that receive state or federal money, which is tied to higher standards, have higher costs than other types of centers. There is no evidence of efficiency differences across various types of providers within a given state either. These results are in contrast to earlier studies which used much less detailed data and concluded that nonprofit child care centers were relatively inefficient (e.g. Irene Powell and James Cosgrove, 1992; Swati Mukerjee, et al., 1990),

The sample mean of the quality index of the centers scaled to the ECERS instrument is 4.0 , with a standard deviation of 0.85 . Previous research that presented the link between quality of care and child outcomes employed the exact same quality index, which ranges from 1 to 7 . The indication is that a score of 3.0 reflects "minimal" quality, whereas a 5.0 or above represents "good" quality. This means that the average center in our sample must increase its quality by 25 percent to achieve good quality. Using the estimated coefficient of the quality index $\left(\eta_{1}\right)$, this brings about an 8 percent increase in total variable costs for the average center. The mean value of the total variable costs for centers is $\$ 224,899$. This implies that an increase in the quality level of an average center to the level considered "good" by education experts would be associated with an additional cost of $\$ 18,048$ per year. Given that the average center provides a total of 137,017 hours of service to infant-toddlers, preschoolers and kinder garden-school age children in a year, it would cost an additional 13 cents per hour per child to produce good quality for an average center, keeping constant the space, the hours of service provided, and the wages paid to staff. 


\section{Conclusion}

Using a newly compiled data set, this paper estimates multi-product translog cost functions for 399 child care centers from California, Colorado, Connecticut, and North Carolina. Quality of child care is controlled by a quality index, based on various center characteristics, and which has been shown to be positively related to child outcomes by previous research. Nonprofit centers that receive public money, either from the state or federal government, (which is tied to higher standards), have total variable costs that are 18 percent higher than other centers, keeping quality of services constant. No statistically significant differences between general categories of for-profit and nonprofit centers are detected. Furthermore, various types of nonprofits (publicly supported, publicly operated, etc.) are not distinguishable from their for-profit counterparts (whether they are independently owned and operated or part of a national chain).

These results indicate that, with the exception of a particular segment of the nonprofit sector, there are no efficiency differences between for-profit and nonprofit sectors in terms of producing child care services. In agreement with previous studies, the data show that the average quality of center-based child care is between "minimal" and "good", and it costs 13 cents per hour per child to increase this average quality to the level considered developmentally appropriate by child care experts. 
TABLE 1

Estimated Translog Cost Function for Child Care Centers

\begin{tabular}{|c|c|c|c|}
\hline Variables & Parameter & Coefficient & $\begin{array}{c}\text { Standard } \\
\text { Error } \\
\end{array}$ \\
\hline Constant & $\alpha_{0}$ & $12.468^{*}$ & 0.048 \\
\hline INFANT-TODD & $\lambda_{1}$ & $0.270^{*}$ & 0.032 \\
\hline PRESCHOOL & $\lambda_{2}$ & $0.241^{*}$ & 0.038 \\
\hline SCHOOLAGE & $\lambda_{3}$ & $0.146^{*}$ & 0.024 \\
\hline WAGE1 & $\alpha_{1}$ & $0.434^{*}$ & 0.013 \\
\hline WAGE2 & $\alpha_{2}$ & $0.238^{*}$ & 0.011 \\
\hline WAGE3 & $\alpha_{3}$ & $0.328^{*}$ & 0.008 \\
\hline SPACE & $\beta_{1}$ & $0.219^{*}$ & 0.041 \\
\hline QUALITY & $\eta_{1}$ & $0.321^{*}$ & 0.078 \\
\hline PROFIT & $\omega_{1}$ & -0.006 & 0.033 \\
\hline CHAIN & $\omega_{2}$ & -0.035 & 0.050 \\
\hline PUBREGUL & $\omega_{3}$ & $0.169^{\circ}$ & 0.062 \\
\hline PUBSUPP & $\omega_{4}$ & 0.031 & 0.049 \\
\hline PUBAUSP & $\omega_{5}$ & 0.015 & 0.059 \\
\hline CALIFORNIA & $\omega_{6}$ & $-0.108^{*}$ & 0.042 \\
\hline COLORADO & $\omega_{7}$ & -0.009 & 0.040 \\
\hline NORTH CAROLINA & $\omega_{8}$ & $-0.132^{*}$ & 0.044 \\
\hline $\mathrm{N}$ & 399 & & \\
\hline Adjusted- $\mathrm{R}^{2}$ & 0.78 & & \\
\hline
\end{tabular}

Note: ${ }^{*}$ indicates significance at 1 percent or better. 


\section{REFERENCES}

Amett, Jeffrey. "Caregivers in Day-Care Centers: Does Training Matter?" Journal of Applied Developmental Psychology, 1989, 10, pp.541-552.

Harms, Thelma; Cryer, Deborah and Clifford, Richard. Infant/Toddler Environment Rating Scale. New York: Teachers College Press, 1990.

Harms, Thelma and Clifford, Richard. Early Childhood Environment Rating Scale. New York: Teachers College Press, 1980.

Hofferth, Sandra; Brayfield, April; Deich, Sharon and Holcomb, Pamela. The National Child Care Survey, 1990. Washington, D.C: The Urban Institute Press, 1991.

Howes, Carollee, and Stewart, Phyliss "Child's Play with Adults, Toys and Peers: An Examination of Family and Child Care Influences, " Developmental Psychology, 1987, 23(3), pp. 423-430.

Kennedy, Peter. "Estimation with Correctly Interpreted Dummy Variables in Semilogarithmic Equations," American Economic Review. September 1981, 71, p. 801 .

Lazar, Irving and Darlington, Richard. "Lasting Effects of Early Education: A Report from the Consortium for Longitudinal Studies." Chicago: University of Chicago Press, 1982.

Mocan, Naci. "Economies of scale, economies of scope, wage elasticities and factor substitution in child care industry," mimeo. University of Colorado at Denver, 1995.

Mukerjee, Swati, and Witte, Ann Dryden. "Cost Functions for for Profit-Making and Not-for-Profit Day Care Centers," Journal of Productivity Analysis. June 1993, pp. 145-63.

Powell, Irene and Cosgrove James. "Quality and Cost in Early Childhood Education," Journal of Human Resources, Summer 1992, 27, pp. 472-83.

Preston, Anne. "Efficiency, Quality, and Social Externalities in the Provision of Day Care: Comparisons of Nonprofit and For-profit Firms," Journal of Productivity Analysis. June 1993, pp . 165-82. 
Ramey, Craig and Campbell, Frances. "Poverty, Early Childhood Education and Academic Competence; The Abecedarian Experiment," in A. Houston, ed., Children in Poverty: Child Development and Public Policy. New York: Cambridge University Press, 1991, pp.190-221.

Stipek, Deborah Attitudes/Perceptions of Competence, unpublished rating scale, 1993. U.S. Department of Commerce. Who's Minding The Kids? Child Care Arrangements, Fall 1988. Washington, D.C. 1992.

Whitebook, Marcy; Howes, Carollee and Phillips, Deborah. "Who Cares? Child Care Teachers and the Quality of Care in America." Final Report of the National Child Care Staffing Study. Oakland, CA: Child Care Employee Project, 1990. 
FOOTNOTES

1. The value of volunteer services is calculated by multiplying the volunteer hours by the wage rate of the paid labor doing similar work.

2. Missing salaries of owner-directors are imputed in three different ways. i) They were assigned the average salary of administrative directors in the same state, same sector (profit or non-profit) and similar center size, ii) by multiplying the highest wage at the center with the hours worked by owner-director, iii) by multiplying their hours by the highest wage at the center plus 23 percent, which is the mean premium a director receives above the highest wage of the center. The results were insensitive to the method.

3. The details of the results are available from the author upon request.

4. Note that the percentage impact of PUBREGUL on total variable cost is $\exp \left\{\omega_{3}-1 / 2 \operatorname{Var}\left(\omega_{3}\right)\right\}-1$, where $\operatorname{Var}\left(\omega_{3}\right)$ is the variance of $\omega_{3}$ (Peter Kennedy, 1981). 